\title{
Evaluation of Critical Operational Faults of Marine Diesel Generator Engines by Using DEMATEL Method
}

\author{
Veysi BAŞHAN ${ }^{1}$, Hakan DEMIREL ${ }^{2}$ \\ ${ }^{1}$ Yıldız Teknik Üniversitesi, Gemi İnşaatı ve Denizcilik Fakültesi, Türkiye \\ ${ }^{2}$ Bülent Ecevit Üniversitesi, Denizcilik Fakültesi, Türkiye \\ vbashan@yildiz.edu.tr; ORCID ID: https://orcid.org/0000-0002-1070-1754 \\ hakandemirel@beun.edu.tr; ORCID ID: https://orcid.org/0000-0002-7579-7064
}

\begin{abstract}
All the electrical demand of ship are provided by diesel generators (DG). Failure of generators due to breakdown can lead to the blackout of the ship which may suddenly cause serious damage to ship's main and/or auxiliary engines, human health and marine environment or any structure at ship's route. Thus, the planned maintenance and repairs of the generators must be done properly without any deficiency or delay. And even then, since the generators run continuously failures may often occur. In this context, this paper provides a DEMATEL (Decision Making Trial and Evaluation Laboratory) method to evaluate the critical operational faults in marine DGs. The DEMATEL method enables to identify and analyze the important faults of marine $D G$ within the respect to the cause-effect relationship diagram. The obtained results of the research will contribute to ship safety at sea and prevention of hazardous machinery effects.
\end{abstract}

Keywords: Marine Diesel Generator Engine, DEMATEL, Ship, Machinery Faults.

\section{Gemi Dizel Jeneratörlerinde Kritik Operasyonel Arızaların DEMATEL Metoduyla Değerlendirilmesi}

$\ddot{O} \mathbf{z}$

Geminin tüm elektriksel gereksinimleri dizel jeneratörler tarafindan sağlanmaktadır. Jeneratörlerde meydana gelen arızalar geminin kararmasına (çökmesine) neden olabilir ve bu durum aniden gemi ana makinesi veya yardımcı makinelerinde, insan sağlı̆̆ına, deniz çevresine veya geminin rotasındaki herhangi bir yaplya ciddi hasarlar verebilir. Bu yüzden, jeneratörlerin planlı bakım ve onarımları düzgün bir şsekilde eksiksiz ve zamanında yapılmalıdır. Tüm bunlara rağmen, sürekli çalışan jeneratörlerde arızalar olabilmektedir. Bu kapsamda, bu makale gemi dizel jeneratörlerinde kritik operasyonel arızaları DEMATEL (Karar Verme Deneme ve Değerlendirme Laboratuvarı) metoduyla sunmaktadır. DEMATEL metodu gemi dizel motorlarında meydana gelen önemli arıaları sebep-etki ilişkisi diyagramıyla tanımlanma ve analiz etmeye yaramaktadır. Elde edilen sonuçlar, denizde gemi emniyeti ve tehlikeli makine etkilerinin önlenmesine katkıda bulunacaktır.

Anahtar Kelimeler: Gemi Dizel Motoru, DEMATEL, Gemi, Makine Arızaları. 


\section{Introduction}

In many parts of the ships, especially in the engine rooms, there are "SAFETY FIRST" signs. This means that the safety is the most important concept in ship operations since the consequences of any fault at ship engine(s) may cause irreversible damage to human life, engines as well as cargo aboard ship. International Maritime Organization (IMO) [1], known as the rulemaking organization in the maritime sector, has issued many rules and conventions related to safety. The prominent ones are; The International Convention on Standard of Training Certification and Watchkeeping for Seafarer (STCW), The International Convention for the Safety of Life at Sea (SOLAS) and The Convention on the Prevention of Maritime Pollution (MARPOL). However, despite these rules, in the literature, many problems that harm both human health and the environment continue to arise as reported[2]-[5]. Many studies are conducted on the detection of these failures [6]-[10]. The DEMATEL method is also concluded in these studies[11], [12]. Emovon et al. [13] used an averaging technique to include indefinite information acquired from experts to apply solution methods for risk in marine engines. Xi et al. [14] investigated the real observed during the maritime operations on the shores of Shanghai and conducted case studies by Cognitive Reliability Error Analysis Method (CREAM) and DEMATEL method. In the thesis of Emovon [15]various techniques to develop tools for supporting the Reliability Centred Maintenance (RCM) methodology and enhance its efficacy in marine maintenance system applications are presented. Akyuz et al [16] carried out a quantitative ship's fire safety system deficiency analysis with Fuzzy Failure Mode and Effects Analysis (FMEA). Saatçığlu et al [17] studied ship engine room casualty analysis by using decision tree method (DTM) to find the frequent faults in engine room. Mullai and Paulsson [18] designed a conceptual model for analyzing marine accidents by using Structural Equation Modeling (SEM) approach. Nguyen [19] performed an application of analytic hierarchy process (AHP) for estimating risks in ship systems based on the data acquired from experts. Özdemir [20] investigated the causes of occupational accidents that took place in ports and the precautions to be taken by using DEMATEL and TOPSIS (Technique for Order Performance by Similarity to Ideal Solution) methods. Even though the DEMATEL is well known and used in many areas like other methods, such approaches are not common in marine sector problems. Therefore, this study will close the gap of maritime literature. Apart from the prior studies, in this study it is aimed to determine the frequent occurrences of faults in the ship's diesel generator and the relationship among faults and effects by using DEMATEL method.

This paper is organized as follows: the research methodology is presented in section 2. Section 3 describes problems and application of the study by including subsections. The final conclusion of this work is given in section 4 .

\section{Research Methodology}

The DEMATEL technique is presented to solve complex and comprehensive decisionmaking problems [21]. DEMATEL has been generally recognized as one of the practical tools to get the cause and effect relationship between the assessments criteria [22]. It is essentially based on the graph theory which allows investigating and explaining problems by visualization [23]. The method reveals the mutual relationship and the values of influential effect among all the criteria. The fundamental steps of DEMATEL method are briefly described as follows.

Step 1: First step is to build an initial 
direct-relational matrix for pair-wise comparison of the factors. A group of decision-makers who have profound knowledge and experience about the problem is acquired. Then, they are required to assess the direct effect among each pair of fault factors. The linguistic assessments are converted to numerical values. Consequently, the direct-relation matrix is obtained. $\mathrm{A}=\left[a_{i j}\right]$ where $\mathrm{A}$ is a $n x n$ non-negative matrix, $a_{i j}$ represents the direct effect of factor $i$ on factor $j$; and when $i=j$, the diagonal elements $a_{i j}=0$.

Step 2: Secondly, the initial directrelation matrix is normalized by comparing factors in the same way. The normalized direct-relation matrix $D=\left[d_{i j}\right]$, can be acquired through an equation (1). All elements in matrix $D$ are complying with $0 \leq d_{i j} \leq 1$, and all principal diagonal elements are equal to zero.

$$
D=\frac{1}{\max _{1 \leq i \leq n} \sum_{j=1}^{n} a_{i j}}
$$

Step 3: The total-relation matrix $(T)$ is calculated by using the equation (2) where I denotes $n x n$ identity matrix. The element $t_{i j}$ shows the indirect effects that criterion $i$ have on criterion $j$, so that the matrix $T$ gives the total relationship among each pair of factors.

$$
T=D(I-D)^{-1}
$$

Step 4: The sum of rows and columns of matrix $T$ is calculated. $r_{i}$ and $c_{j}$ are resolved according to the equations (3) and (4) respectively. In the formula, while $r_{i}$ denotes all direct and indirect influence given by criterion $i$ to all other factors, $c_{j}$ denotes the degree of influenced effect.

$$
\begin{aligned}
& r_{i}=\sum_{1 \leq j \leq n} t_{i j} \\
& c_{j}=\sum_{1 \leq i \leq n} t_{i j}
\end{aligned}
$$

When $i=j, r_{i}+c_{j}$ shows all effects are given and received by criterion $i$. That is to say, $r_{i}+c_{j}$ expresses both criteria i's impact on the whole system and other system factors impact on factor $i$. So, the indicator $r_{i}+c_{j}$ may show the degree of significance that criterion $i$ plays in the total system. Contrariwise, the difference of the two, $\quad r_{i}-c_{j}$, presents the net effect that criterion $i$ has on the system. Particularly, if the value of $r_{i}-c_{j}$ is positive, the factor $i$ is a net cause, exposing net causal effect on the system. When $r_{i}-c_{j}$ is negative, the factor is a net result gathered into effect group [24], [25].

Step 5: In the latest step, a cause and effect relationship diagram is illustrated according to $r_{i}+c_{j}$ and $r_{i}-c_{j^{\prime}}$ Therefore, the complex interrelationship among factors is visualized through the diagram.

\section{Evaluation of Critical Operational} Failures of Marine Diesel Generator Engines

In this section, DEMATEL approach is applied to evaluate and understand the causes of faults in generators and the interactions of faults with each other. In this way, the relation of the systems to each other will be understood more clearly.

Due to limited knowledge and academic work related to the subject in the literature, relevant marine experts have been consulted. Increasing the number of experts is important for the results of the method to be more precise. In our study, only common problems are mentioned. The handling of all problems may be more useful for literature.

\subsection{Problem Description}

Considering ship DGs, some failures such as starting the generator for the first time, stopping, irregular operation, and problems in some cylinders, in lubrication oil, fresh water cooling cycle and in exhaust outlet are some of the troubles. The most common causes of these situations have been identified. In this context, Table 1 shows critical operational faults in marine DGs. In the Table $1, \mathrm{C}$ denotes faults. 
Table 1. Most Common Faults in DG Engine

\begin{tabular}{|c|c|}
\hline Fault Code & Description \\
\hline $\mathrm{C} 1$ & Piston is seized. \\
\hline $\mathrm{C} 2$ & The bearings are tightened much above the nominal torque values. \\
\hline $\mathrm{C} 3$ & There are unknown objects in the cylinder. \\
\hline $\mathrm{C} 4$ & $\begin{array}{l}\text { There is a fault in the starting system. The start air reservoirs are under low pressure or the air } \\
\text { dryer is faulty and air moist or there is a problem with relay valve. }\end{array}$ \\
\hline $\mathrm{C} 5$ & There is a fault in electrical, electronic systems or starter motor. \\
\hline C6 & The crankshaft cannot rotate at a sufficient speed \\
\hline $\mathrm{C} 7$ & Lubrication oil temperature is too high. \\
\hline C8 & Fuel injection is not occurring. There is a problem with the injector(s). \\
\hline $\mathrm{C} 9$ & The fuel has poor quality. \\
\hline C10 & Insufficient amount of fuel goes to the cylinders. \\
\hline C11 & The exhaust cannot be thrown. \\
\hline $\mathrm{C} 12$ & Pistons or beds are suddenly seized \\
\hline C13 & Fuel filters are plugged. \\
\hline C14 & Combustion does not occur in at least one of the cylinders. \\
\hline C15 & The turbine is surging. \\
\hline $\mathrm{C} 16$ & The generator engine cannot be cooled sufficiently. \\
\hline $\mathrm{C} 17$ & The governor has advanced all the indexes to the end. \\
\hline C18 & Dense amount of fuel dribbled from the injector. \\
\hline C19 & Oil or fuel is mixed into the intake air. \\
\hline $\mathrm{C} 20$ & There is a problem with the cylinder's fuel pump. \\
\hline $\mathrm{C} 21$ & The cylinder's injection lance (pipe) is clogged. \\
\hline $\mathrm{C} 22$ & The tip of the cylinder injectors is covered with carbon. \\
\hline $\mathrm{C} 23$ & There are intense leaks in the valves. \\
\hline $\mathrm{C} 24$ & $\begin{array}{l}\text { The pressure measuring manometer is defective in the relevant circuit. (for low pressure of } \\
\text { cooling oil or water) }\end{array}$ \\
\hline $\mathrm{C} 25$ & The filter of the corresponding station is blocked. (for low pressure of cooling oil or water) \\
\hline $\mathrm{C} 26$ & There is a leak in the relevant circuit. (for low pressure of cooling oil or water) \\
\hline $\mathrm{C} 27$ & The thermocouple is defective. \\
\hline $\mathrm{C} 28$ & There is a problem with cylinder cooling. \\
\hline $\mathrm{C} 29$ & There is a problem with fuel advance. \\
\hline $\mathrm{C} 30$ & Fuel index and VIT have problems. \\
\hline C31 & The machine is overloaded and the load is fluctuating. \\
\hline $\mathrm{C} 32$ & The piston rings are completely worn. \\
\hline $\mathrm{C} 33$ & Fuel injection advance has problem. \\
\hline
\end{tabular}




\subsection{Evaluation of Respondents}

Because of the limited data in marine industry, experts' judgements are preferred commonly. On ships, there are chief engineers, second engineers and third engineers responsible from ships all engines and machineries. The chief engineer is responsible for all the work in the engine room, and the job is shared among the engineers. Under the supervision of chief engineer, most of the operations are carried out by the second engineer and the third engineer. The third engineer is responsible for the maintenance and repair of the DGs, one of the important auxiliary engines at the ship. Likewise, the compressors are the third engineer's responsibility. Because of the experience of the chief engineers, two of our experts were selected as chief engineers with at least 5 years of experience as chief engineer and one of them was selected as experienced third engineer which also have MSc degree. The problems encountered in the DG were asked to these 3 experts and the relationship between the probable causes and reasons and the effects of the causes on each other were examined.

It has been understood that the results of evaluating the answers given by the experts give overlapping results with the DEMATEL method.

\subsection{Application of Proposed Method}

First of all, the critical operational faults in marine DG are presented to the marine experts in order to investigate the interaction among each pair of critical faults as provided in Table 1 . In accordance with the consensus of experts, Table 2 shows the aggregation matrix. Accordingly, Table 3 demonstrates the normalized decision matrix. Thereafter, Table 4 illustrates total-relation matrix. In the light of above outcomes, the crisp values of

$\tilde{r_{i}}$, $\tilde{c_{j}}, \tilde{r_{i}}+\tilde{c_{j}}, \tilde{r_{i}}-\tilde{c_{j}}$ can be obtained as illustrated in Table 5. In the last stage, cause and effect relationship diagram can be depicted based on the above outcomes.

\subsection{Findings}

In the light of calculation of the $r_{i}, c_{j}, r_{i}+c_{j}, r_{i}-c_{j}$, Figure 1 shows the causeeffect relation diagram. According to the diagram, it may be necessary to divide the findings into two groups as causes and effects.

Table 2. Aggregation Matrix

\begin{tabular}{|l|l|l|l|l|l|l|l|l|l|l|l|l|l|}
\hline & C1 & C2 & C3 & C4 & C5 & $\ldots$ & C27 & C28 & C29 & C30 & C31 & C32 & C33 \\
\hline C1 & 0.00 & 0.33 & 2.33 & 0.00 & 0.00 & $\ldots$ & 0.00 & 4.00 & 1.67 & 2.00 & 1.67 & 4.00 & 2.00 \\
\hline C2 & 0.00 & 0.00 & 0.00 & 0.00 & 0.00 & $\ldots$ & 0.00 & 0.00 & 0.00 & 0.00 & 0.00 & 0.00 & 0.00 \\
\hline C3 & 2.67 & 0.00 & 0.00 & 0.00 & 0.00 & $\ldots$ & 0.00 & 0.00 & 0.00 & 0.00 & 0.33 & 1.00 & 0.00 \\
\hline C4 & 0.00 & 0.00 & 0.00 & 0.00 & 0.33 & $\ldots$ & 0.00 & 1.33 & 0.00 & 0.00 & 0.67 & 0.00 & 0.00 \\
\hline C5 & 0.00 & 0.00 & 0.00 & 0.33 & 0.00 & $\ldots$ & 0.00 & 0.33 & 0.33 & 0.00 & 0.00 & 0.00 & 0.33 \\
\hline$\ldots$ & $\ldots$ & $\ldots$ & $\ldots$ & $\ldots$ & $\ldots$ & $\ldots$ & $\ldots$ & $\ldots$ & $\ldots$ & $\ldots$ & $\ldots$ & $\ldots$ & $\ldots$ \\
\hline C27 & 0.00 & 0.00 & 0.00 & 0.00 & 0.00 & $\ldots$ & 0.00 & 1.33 & 0.00 & 0.00 & 0.67 & 0.67 & 0.00 \\
\hline C28 & 1.00 & 2.00 & 1.33 & 0.00 & 0.67 & $\ldots$ & 2.67 & 0.00 & 1.33 & 1.33 & 3.33 & 2.67 & 0.67 \\
\hline C29 & 0.00 & 0.00 & 0.00 & 0.00 & 0.00 & $\ldots$ & 0.00 & 0.00 & 0.00 & 3.67 & 2.00 & 0.00 & 4.00 \\
\hline C30 & 0.00 & 0.00 & 0.00 & 0.00 & 0.00 & $\ldots$ & 0.00 & 0.67 & 1.67 & 0.00 & 3.00 & 1.00 & 3.33 \\
\hline C31 & 3.67 & 2.00 & 3.00 & 0.00 & 0.00 & $\ldots$ & 0.00 & 1.33 & 1.33 & 3.33 & 0.00 & 1.67 & 1.33 \\
\hline C32 & 3.67 & 0.00 & 3.00 & 0.00 & 0.00 & $\ldots$ & 0.00 & 2.67 & 1.33 & 1.33 & 2.33 & 0.00 & 1.00 \\
\hline C33 & 0.00 & 0.00 & 0.00 & 0.00 & 0.00 & $\ldots$ & 0.00 & 0.00 & 3.67 & 3.67 & 3.33 & 1.33 & 0.00 \\
\hline
\end{tabular}


Table 3. Normalized Decision Matrix

\begin{tabular}{|l|l|l|l|l|l|l|l|l|l|l|l|l|l|}
\hline & C1 & C2 & C3 & C4 & C5 & $\ldots$ & C27 & C28 & C29 & C30 & C31 & C32 & C33 \\
\hline C1 & 0.00 & 0.01 & 0.05 & 0.00 & 0.00 & $\ldots$ & 0.00 & 0.09 & 0.04 & 0.04 & 0.04 & 0.09 & 0.04 \\
\hline C2 & 0.00 & 0.00 & 0.00 & 0.00 & 0.00 & $\ldots$ & 0.00 & 0.00 & 0.00 & 0.00 & 0.00 & 0.00 & 0.00 \\
\hline C3 & 0.06 & 0.00 & 0.00 & 0.00 & 0.00 & $\ldots$ & 0.00 & 0.00 & 0.00 & 0.00 & 0.01 & 0.02 & 0.00 \\
\hline C4 & 0.00 & 0.00 & 0.00 & 0.00 & 0.01 & $\ldots$ & 0.00 & 0.03 & 0.00 & 0.00 & 0.01 & 0.00 & 0.00 \\
\hline C5 & 0.00 & 0.00 & 0.00 & 0.01 & 0.00 & $\ldots$ & 0.00 & 0.01 & 0.01 & 0.00 & 0.00 & 0.00 & 0.01 \\
\hline$\ldots$ & $\ldots$ & $\ldots$ & $\ldots$ & $\ldots$ & $\ldots$ & $\ldots$ & $\ldots$ & $\ldots$ & $\ldots$ & $\ldots$ & $\ldots$ & $\ldots$ & $\ldots$ \\
\hline C27 & 0.00 & 0.00 & 0.00 & 0.00 & 0.00 & $\ldots$ & 0.00 & 0.03 & 0.00 & 0.00 & 0.01 & 0.01 & 0.00 \\
\hline C28 & 0.02 & 0.04 & 0.03 & 0.00 & 0.01 & $\ldots$ & 0.06 & 0.00 & 0.03 & 0.03 & 0.07 & 0.06 & 0.01 \\
\hline C29 & 0.00 & 0.00 & 0.00 & 0.00 & 0.00 & $\ldots$ & 0.00 & 0.00 & 0.00 & 0.08 & 0.04 & 0.00 & 0.09 \\
\hline C30 & 0.00 & 0.00 & 0.00 & 0.00 & 0.00 & $\ldots$ & 0.00 & 0.01 & 0.04 & 0.00 & 0.07 & 0.02 & 0.07 \\
\hline C31 & 0.08 & 0.04 & 0.07 & 0.00 & 0.00 & $\ldots$ & 0.00 & 0.03 & 0.03 & 0.07 & 0.00 & 0.04 & 0.03 \\
\hline C32 & 0.08 & 0.00 & 0.07 & 0.00 & 0.00 & $\ldots$ & 0.00 & 0.06 & 0.03 & 0.03 & 0.05 & 0.00 & 0.02 \\
\hline C33 & 0.00 & 0.00 & 0.00 & 0.00 & 0.00 & $\ldots$ & 0.00 & 0.00 & 0.08 & 0.08 & 0.07 & 0.03 & 0.00 \\
\hline
\end{tabular}

Table 4. Total Relation Matrix

\begin{tabular}{|l|l|l|l|l|l|l|l|l|l|l|l|l|l|}
\hline & C1 & C2 & C3 & C4 & C5 & $\ldots$ & C27 & C28 & C29 & C30 & C31 & C32 & C33 \\
\hline C1 & 0.07 & 0.05 & 0.12 & 0.01 & 0.01 & $\ldots$ & 0.03 & 0.15 & 0.09 & 0.12 & 0.12 & 0.16 & 0.11 \\
\hline C2 & 0.01 & 0.00 & 0.01 & 0.00 & 0.00 & $\ldots$ & 0.00 & 0.01 & 0.00 & 0.00 & 0.01 & 0.01 & 0.00 \\
\hline C3 & 0.08 & 0.02 & 0.03 & 0.01 & 0.00 & $\ldots$ & 0.01 & 0.03 & 0.02 & 0.03 & 0.03 & 0.05 & 0.02 \\
\hline C4 & 0.01 & 0.01 & 0.02 & 0.01 & 0.01 & $\ldots$ & 0.01 & 0.04 & 0.01 & 0.02 & 0.03 & 0.02 & 0.01 \\
\hline C5 & 0.01 & 0.01 & 0.01 & 0.01 & 0.00 & $\ldots$ & 0.00 & 0.01 & 0.02 & 0.01 & 0.01 & 0.01 & 0.02 \\
\hline$\ldots$ & $\ldots$ & $\ldots$ & $\ldots$ & $\ldots$ & $\ldots$ & $\ldots$ & $\ldots$ & $\ldots$ & $\ldots$ & $\ldots$ & $\ldots$ & $\ldots$ & $\ldots$ \\
\hline C27 & 0.01 & 0.01 & 0.01 & 0 & 0 & $\ldots$ & 0.01 & 0.04 & 0.01 & 0.01 & 0.03 & 0.03 & 0.01 \\
\hline C28 & 0.09 & 0.08 & 0.1 & 0.02 & 0.02 & $\ldots$ & 0.08 & 0.06 & 0.08 & 0.1 & 0.15 & 0.12 & 0.07 \\
\hline C29 & 0.04 & 0.02 & 0.04 & 0.01 & 0.01 & $\ldots$ & 0.01 & 0.03 & 0.05 & 0.15 & 0.1 & 0.04 & 0.14 \\
\hline C30 & 0.06 & 0.03 & 0.07 & 0.02 & 0.02 & $\ldots$ & 0.01 & 0.06 & 0.1 & 0.09 & 0.14 & 0.08 & 0.14 \\
\hline C31 & 0.14 & 0.07 & 0.13 & 0.02 & 0.01 & $\ldots$ & 0.02 & 0.08 & 0.09 & 0.15 & 0.08 & 0.1 & 0.09 \\
\hline C32 & 0.15 & 0.04 & 0.14 & 0.02 & 0.01 & $\ldots$ & 0.03 & 0.12 & 0.08 & 0.1 & 0.13 & 0.07 & 0.08 \\
\hline C33 & 0.04 & 0.02 & 0.05 & 0.01 & 0.01 & $\ldots$ & 0.01 & 0.03 & 0.12 & 0.14 & 0.13 & 0.07 & 0.06 \\
\hline
\end{tabular}

\subsubsection{Cause Factors}

In order to asses the critical and operational faults in the course of DG operation, it is necessary to focus on the cause factor of fault analysis which requires more attention. In the view of Figure 1, C14 (Combustion does not occur in at least one of the cylinders) has the highest $r_{i}-c_{j}$ value among the all factors in cause group. This means that C14 has more impact on the whole process. Afterwards, C17 (The governor has advanced all the indexes to the end) is the second most important causal factor since it ranks second place among the all factors. Consequently, it has huge impact on the entire DG operations. The third most important factor among the entire process is C7 (Lubrication oil temperature is too high) ranks third place among the process. Likewise, C10 (Insufficient amount of fuel 
Table 5. Crisp Values of $\tilde{r}_{i}, \tilde{c_{j}}, r_{i}^{\sim}+c_{j}, \tilde{r}_{i}^{\sim}-\tilde{c}_{j}$

\begin{tabular}{|l|l|l|l|l|l|l|l|l|l|}
\hline & $\mathbf{R}_{\mathbf{i}}$ & $\mathbf{C}_{\mathbf{j}}$ & $\mathbf{R}_{\mathrm{i}}+\mathbf{C}_{\mathbf{j}}$ & $\mathbf{R}_{\mathrm{i}}-\mathbf{C}_{\mathbf{j}}$ & & $\mathbf{R}_{\mathbf{i}}$ & $\mathbf{C}_{\mathbf{i}}$ & $\mathbf{R}_{\mathrm{i}}+\mathbf{C}_{\mathbf{i}}$ & $\mathbf{R}_{\mathrm{i}}-\mathbf{C}_{\mathbf{i}}$ \\
\hline $\mathbf{C 1}$ & 2.49 & 1.79 & 4.28 & 0.70 & $\mathbf{C 1 8}$ & 1.22 & 1.72 & 2.94 & -0.51 \\
\hline $\mathbf{C 2}$ & 0.15 & 1.00 & 1.15 & -0.85 & $\mathbf{C 1 9}$ & 0.29 & 1.26 & 1.56 & -0.97 \\
\hline $\mathbf{C 3}$ & 0.97 & 2.09 & 3.06 & -1.12 & $\mathbf{C 2 0}$ & 1.09 & 2.00 & 3.08 & -0.91 \\
\hline $\mathbf{C 4}$ & 0.69 & 0.62 & 1.31 & 0.07 & $\mathbf{C 2 1}$ & 1.09 & 1.43 & 2.52 & -0.34 \\
\hline $\mathbf{C 5}$ & 0.37 & 0.41 & 0.79 & -0.04 & $\mathbf{C 2 2}$ & 1.62 & 1.46 & 3.09 & 0.16 \\
\hline C6 & 1.82 & 1.46 & 3.28 & 0.37 & $\mathbf{C 2 3}$ & 0.86 & 0.96 & 1.82 & -0.10 \\
\hline C7 & 3.00 & 1.77 & 4.77 & 1.23 & $\mathbf{C 2 4}$ & 0.39 & 0.38 & 0.76 & 0.01 \\
\hline C8 & 1.75 & 1.81 & 3.56 & -0.05 & $\mathbf{C 2 5}$ & 0.84 & 2.34 & 3.18 & -1.49 \\
\hline C9 & 0.88 & 2.69 & 3.56 & -1.81 & $\mathbf{C 2 6}$ & 1.14 & 1.67 & 2.82 & -0.53 \\
\hline C10 & 2.41 & 1.37 & 3.78 & 1.03 & $\mathbf{C 2 7}$ & 0.43 & 0.62 & 1.05 & -0.18 \\
\hline C11 & 1.37 & 1.77 & 3.14 & -0.39 & $\mathbf{C 2 8}$ & 2.50 & 1.63 & 4.13 & 0.86 \\
\hline C12 & 2.65 & 2.42 & 5.08 & 0.23 & $\mathbf{C 2 9}$ & 1.95 & 1.78 & 3.74 & 0.17 \\
\hline C13 & 1.00 & 1.79 & 2.78 & -0.79 & $\mathbf{C 3 0}$ & 2.61 & 2.43 & 5.04 & 0.18 \\
\hline C14 & 3.12 & 0.90 & 4.02 & 2.22 & $\mathbf{C 3 1}$ & 2.47 & 2.33 & 4.80 & 0.14 \\
\hline C15 & 0.74 & 0.66 & 1.40 & 0.08 & $\mathbf{C 3 2}$ & 2.47 & 1.98 & 4.45 & 0.49 \\
\hline C16 & 1.81 & 1.56 & 3.37 & 0.25 & $\mathbf{C 3 3}$ & 1.90 & 2.02 & 3.92 & -0.11 \\
\hline C17 & 3.39 & 1.39 & 4.78 & 2.01 & & & & & \\
\hline
\end{tabular}

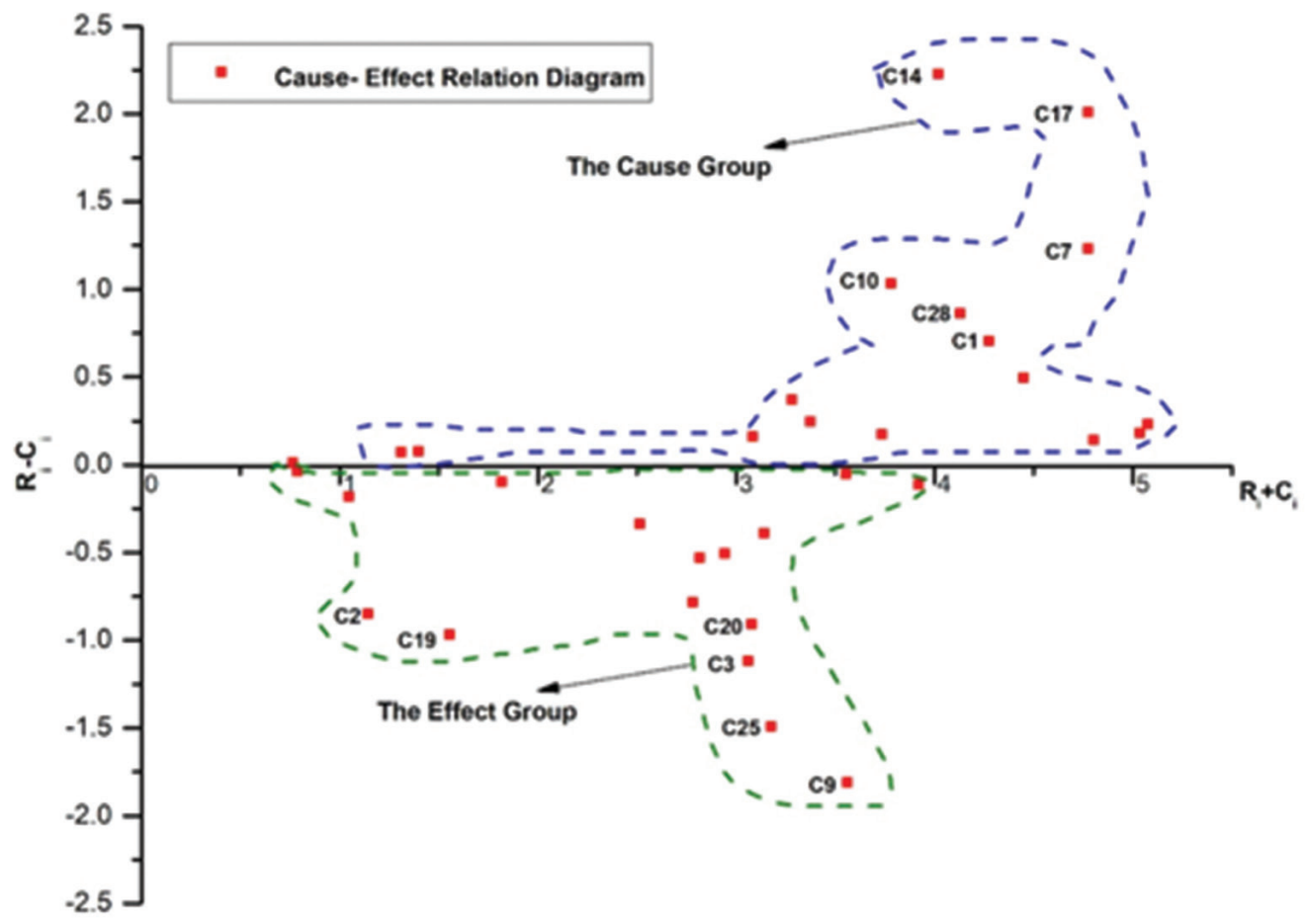

Figure 1. Cause-Effect Relation Diagram 
goes to the cylinders) is another important factor among the whole process. This order of importance continues in the form of C28 (There is a problem with cylinder cooling), C1 (seizure of piston) and C32 (The piston rings are completely worn). Other fault codes have relatively moderatelow influence on the DG operations since their $r_{i}-c_{j}$ value as well as $r_{i}$ values in the operations are not high enough.

\subsubsection{Effect Factors}

Although the influence factors of failures in diesel generators are influenced by other factors, they need to be investigated with great care because these effects can have very serious consequences in a chained way. With the guidance of the cause-effect relation diagram, results show that C33 (Fuel injection advance has problem) has the highest $r_{i}+c_{j}$ value (3.92) among all effect factors. Moreover, it is degree of influential impact index $\left(r_{i}\right)$ and influenced impact index $\left(c_{j}\right)$ values $(1.92 ; 2.02)$ are the quite high degree among the all process. The $r_{i}-c_{j}$ value of C33 is close to the average value compared to other factors in the effect group, not very low. For this reason, it is understood that C33 has a significant effect on the other factors. Thereafter, C8 (Fuel injection is not occurring. There is a problem with the injectors) and C9 (The fuel has poor quality) have the second highest $r_{i}+c_{j}$ values (3.56) among effect factors in the whole process. However, when C9's $\quad r_{i}-c_{j}$ value is investigated it can be seen that it is very low $(-1.81)$ which means that it can easily be affected by the other factors. Also, when the cause- effect diagram data is examined, it is seen that C25 (The filter of the corresponding station is blocked for low pressure of cooling oil or water) comes in the third place (3.18) in terms of $r_{i}+c_{j}$ values. As can be seen in the cause effect diagram, the rest of the factors have relatively moderate $r_{i}+c_{j}$ values. Their $r_{i}-c_{j}$ values are comparatively low which indicates a powerful influenced degree.

\section{Conclusion}

Safety and security measures at sea must be practiced to protect the environment, machines, and especially human life. In marine engines, planned maintenance and repair are therefore very important. If planned maintenance-repair is not done, many faults can be encountered. Rarely, unexpected failures can occur despite scheduled maintenance. A breakdown can sometimes have multiple causes and a breakdown can trigger another. For this reason, it is essential to know the ship auxiliary engine systems and their relation to each other. In this study, some failures in DGs have been analyzed. The first start of the DG, stopping of DG, the fuel system, the lubrication and cooling systems, the faults in some physical equipment etc. have been investigated. In terms of results, it is understood that, when the causes and effects are examined in case of faults in the DG, the fuel system and the combustion, lubrication and cooling systems are relatively more important in terms of the reasons. From the point of effects, it is seen that the most important ones are fuel injection advance, fuel injection, fuel quality and filtration. This study will help marine engineers, especially oceangoing engineers to understand the causes of common problems in DGs and their relationship to each other. For future work, by understanding the relation between problems occurring in DGs, it may be possible to develop wonderful preventive systems such as the prediction of failures. The obtained results of the research will contribute to ship safety at sea and prevention of hazardous machinery effects. 


\section{References}

[1] "International Maritime Organization." [Online]. Available: http://www.imo. org/en/Pages/Default.aspx. [Accessed: 03-Jan-2018].

[2] N. Akten, (2006). "Shipping accidents: a serious threat for marineenvironment," Journal of Black Sea/Mediterranean Environment, vol. 12, no. 3.

[3] J. U. Schröder-Hinrichs, M. Baldauf, and K. T. Ghirxi, (2011). "Accident investigation reporting deficiencies related to organizational factors in machinery space fires and explosions," Accident Analysis \& Prevention, vol. 43, no. 3, pp. 1187-1196.

[4] Y. Papadopoulos et al., (2011). "Engineering failure analysis and design optimisation with HiP-HOPS," Engineering Failure Analysis, vol. 18, no. 2 , pp. 590-608.

[5] K. Cicek and M. Celik, (2013). "Application of failure modes and effects analysis to main engine crankcase explosion failure on-board ship," Safety Science, vol. 51, no. 1, pp. 6-10.

[6] A. Jardine, P. Anderson, and D. Mann, (1987). "Application of the Weibull proportional hazards model to aircraft and marine engine failure data," Quality and reliability engineering international, vol. 3, no. 2, pp. 77-82.

[7] A. Jardine, P. Ralston, N. Reid, and J. Stafford, (1989). "Proportional hazards analysis of diesel engine failure data," Quality and Reliability Engineering International, vol. 5, no. 3, pp. 207-216.

[8] M. Fonte, P. Duarte, V. Anes, M. Freitas, and L. Reis, (2015). "On the assessment of fatigue life of marine diesel engine crankshafts," Engineering Failure Analysis, vol. 56, pp. 51-57.

[9] C. Cai, X. Weng, and C. Zhang, (2017). "A novel approach for marine diesel engine fault diagnosis," Cluster Computing, pp. 1-12.
[10] 0. A. Özsoysal, (2008). Gemi dizel motorları arızalar ve nedenleri. Ankara: Nobel Yayın Dağıtım.

[11] E. Akyuz and E. Celik, (2015). "A fuzzy DEMATEL method to evaluate critical operational hazards during gas freeing process in crude oil tankers," Journal of Loss Prevention in the Process Industries, vol. 38, pp. 243-253.

[12] A. Mentes, H. Akyildiz, M. Yetkin, and N. Turkoglu,(2015). "A FSA based fuzzy DEMATEL approach for risk assessment of cargo ships at coasts and open seas of Turkey," Safety science, vol. 79, pp. 1-10.

[13] I. Emovon, R. A. Norman, A. Murphy J., and K. Pazouki, (2015). "An integrated multicriteria decision making methodology using compromise solution methods for prioritising risk of marine machinery systems," Ocean Engineering, vol. 105, pp. 92-103.

[14] Y. T. Xi, Z. L. Yang, Q. G. Fang, W. J. Chen, and J. Wang, (2017). "A new hybrid approach to human error probability quantification-applications in maritime operations," Ocean Engineering, vol. 138, pp. 45-54.

[15] Ikuobase Emovon, (2016). "MultiCriteria Decision Making Support Tools For Maintenance of Marine Machinery Systems," Newcastle Unıversity, School of Marine Science and Technology.PhD Thesis.

[16] E. Akyuz, I. Akgun, and M. Celik, (2016). "A fuzzy failure mode and effects approach to analyse concentrated inspection campaigns on board ships," Maritime Policy \& Management, vol. 43, no. 7, pp. 887-908.

[17] Ö. Y. Saatçıoğlu, B. Göksu, O. Yüksel, and Y. Gülmez, (2017). "Ship Engine Room Casualty Analysis by Using Decision Tree Method," Journal of ETA Maritime Science, vol. 5, no. 1, pp. 5968. 
[18] A. Mullai and U. Paulsson, (2011). "A grounded theory model for analysis of marine accidents," Accident Analysis \& Prevention, vol. 43 , no. 4, pp. 1590 1603.

[19] H. Nguyen, (2009). "The application of the ahp method in ship system risk estimation," Polish Maritime Research, vol. 16, no. 1.

[20] Ü. Özdemir, (2016). "Investigation of occupational accidents occurred in ports by using fuzzy DEMATEL and fuzzy TOPSIS methods," Journal of ETA Maritime Science, vol. 4, no. 3, pp. 235-247.

[21] A. Gabus and E. Fontela, (1972). "World problems, an invitation to further thought within the framework of DEMATEL,"Battelle Geneva Research Center, Geneva, Switzerland.

[22] C.-L. Lin and G.-H. Tzeng, (2009). "A value-created system of science (technology) park by using DEMATEL,"Expert systems with applications, vol. 36, no. 6, pp. $9683-$ 9697.

[23] R.-J. Lin, (2013). "Using fuzzy DEMATEL to evaluate the green supply chain management practices," Journal of Cleaner Production, vol. 40, pp. 32-39.

[24] Y.-P. O. Yang, H.-M. Shieh, J.-D. Leu, and G.-H. Tzeng, (2008). "A novel hybrid MCDM model combined with DEMATEL and ANP with applications," International journal of operations research, vol. 5, no. 3, pp. 160-168.

[25] A. H. Lee, H.-Y. Kang, C.-F. Hsu, and H.-C. Hung, (2009)."A green supplier selection model for hightech industry," Expert systems with applications, vol. 36, no. 4, pp. 79177927. 